BORDERSCAPING: IMAGINATIONS AND PRACTICES OF BORDER MAKING 


\section{Border Regions Series}

Series Editor: Doris Wastl-Walter, University of Bern, Switzerland

In recent years, borders have taken on an immense significance. Throughout the world they have shifted, been constructed and dismantled, and become physical barriers between socio-political ideologies. They may separate societies with very different cultures, histories, national identities or economic power, or divide people of the same ethnic or cultural identity.

As manifestations of some of the world's key political, economic, societal and cultural issues, borders and border regions have received much academic attention over the past decade. This valuable series publishes high quality research monographs and edited comparative volumes that deal with all aspects of border regions, both empirically and theoretically. It will appeal to scholars interested in border regions and geopolitical issues across the whole range of social sciences. 


\title{
Borderscaping: Imaginations and Practices of Border Making
}

\author{
Edited by \\ CHIARA BRAMBILLA \\ University of Bergamo, Italy \\ JUSSI LAINE \\ University of Eastern Finland, Finland \\ JAMES W. SCOTT \\ University of Eastern Finland, Finland \\ GIANLUCA BOCCHI \\ University of Bergamo, Italy
}


All rights reserved. No part of this publication may be reproduced, stored in a retrieval system or transmitted in any form or by any means, electronic, mechanical, photocopying, recording or otherwise without the prior permission of the publisher.

Chiara Brambilla, Jussi Laine, James W. Scott and Gianluca Bocchi have asserted their right under the Copyright, Designs and Patents Act, 1988, to be identified as the editors of this work.

Published by

Ashgate Publishing Limited

Ashgate Publishing Company

Wey Court East

110 Cherry Street

Union Road

Suite 3-1

Farnham

Burlington, VT 05401-3818

Surrey, GU9 7PT

USA

England

www.ashgate.com

British Library Cataloguing in Publication Data

A catalogue record for this book is available from the British Library.

\section{Library of Congress Cataloging-in-Publication Data}

Borderscaping : imaginations and practices of border making / edited by Chiara Brambilla, Jussi Laine, James W. Scott and Gianluca Bocchi.

pages $\mathrm{cm}$. -- (Border regions series)

Includes bibliographical references and index.

ISBN 978-1-4724-5146-0 (hardback) -- ISBN 978-1-4724-5147-7 (ebook) -- ISBN 978-1-4724-5148-4

(epub) 1. Boundaries--Social aspects--Case studies. 2. Boundaries--Political aspects--Case studies. 3.

Borderlands--Social aspects--Case studies. 4. Borderlands--Political aspects--Case studies. I. Brambilla,

Chiara. II. Laine, Jussi. III. Scott, James Wesley. IV. Bocchi, Gianluca.

GF53.B67 2015

320.1 '2--dc23

2015012108

ISBN 9781472451460 (hbk)

ISBN 9781472451477 (ebk - PDF)

ISBN 9781472451484 (ebk - ePUB)

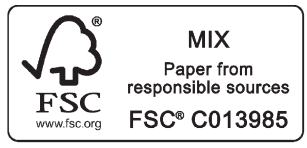

Printed in the United Kingdom by Henry Ling Limited, at the Dorset Press, Dorchester, DT1 1HD 


\section{Contents}

List of Figures and Tables vii

Notes on Contributors $\quad$ ix

Dedication $x v$

List of Abbreviations $\quad$ xvii

Introduction: Thinking, Mapping, Acting and Living Borders

under Contemporary Globalisation

Chiara Brambilla, Jussi Laine, James W. Scott and Gianluca Bocchi

\section{PART I: CONCEPTUAL CHANGE IN THINKING BORDERS}

1 Spaces, Lines, Borders: Imaginaries and Images

Anna Krasteva

2 Beyond Constructivism: Europeanisation and Bordering under the Impact of Power and Imaginaries

Hans-Joachim Bürkner

3 Redesigning Borderlands: Using the Janus-Face of Borders as a Resource

Henk van Houtum and Mark Eker

$4 \quad$ New Geo-graphies of Border(land)-scapes

Elena dell'Agnese

\section{PART II: EVERYDAY PROCESSES OF BORDERING}

5 Remaking the Border: Post-Soviet Borderscapes in the Finnish Media

Jussi Laine and Miika Tervonen

6 From Frontline to Borderscape: The Hizbullah Memorial Museum in South Lebanon

Daniel Meier

7 On the Metaphor of the 'Bulgarian Question' in Croatian Literary Narrative:

Enquiring into the Key Bordering Themes of Post-1989 Balkans

Ivana Trkulja

8 The Construction of Socio-Spatial Identities alongside the Schengen Border:

Bordering and Border-Crossing Processes in the Croatian-Slovenian Borderlands

Marta Zorko

\section{PART III: EXPLORING SHIFTING EURO/MEDITERRANEAN BORDERSCAPES}

$9 \quad$ Navigating the Euro/African Border and Migration Nexus through the Borderscapes Lens: Insights from the LampedusaInFestival 
10 Euro-African Invisibilisations in the Border(land)scape of Punta Tarifa

Xavier Ferrer-Gallardo, Abel Albet-Mas and Keina Espiñeira

11 Humanitarianism and Migration in the Mediterranean Borderscape:

The Italian-North African Border between Sea Patrols and Integration Measures

Paolo Cuttitta

12 Between Asylum and Security: Reconfigurations in the EU/Turkish Borderscapes

Martin Lemberg-Pedersen

13 Cross-Border Cooperation as a Territorial/Relational Approach to Regional Development?

Filippo Celata and Raffaella Coletti

14 Addressing Euro-Mediterranean Border Imaginations from a Project-Based Perspective

Alice Buoli

\section{PART IV: REBORDERING STATE SPACES: CITY BORDERS AND BORDER CITIES}

15 Metamorphosis of City Borders

Anna Lazzarini

16 Everyday Bordering and Raids Every Day: The Invisible Empire and Metropolitan Borderscapes

Georgie Wemyss

17 Living through the Camp: Roma Segregation and Border-Crossing in the City of Naples

Caterina Miele

18 Shifting Borderscapes of London in Monica Ali's Narrative

Maria Cristina Paganoni

\section{PART V: CULTURAL PRODUCTION AND THE EMERGENCE OF NEW BORDERSCAPES}

19 Seeing and Thinking Borders

Holger Pötzsch

20 Borders and Transitive Identities in Jamal Mahjoub's 'Last Thoughts on the Medusa'

Jopi Nyman

21 Operationalising Borders: Euro/African Borderscapes on Stage

Claudia Gualtieri

22 Contemporary Art for Mapping New Borderscapes

Cristina Giudice 